\title{
How facts travel: The model systems of sociology
}

\author{
Monika Krause *, Michael Guggenheim \\ Department of Sociology, Goldsmiths College, University of London, New Cross, \\ London SE14 6NW, United Kingdom
}

\begin{abstract}
The discussion in the sociology of science about the role of model systems in biology provides an invitation to reflect on whether and how they operate in sociology in comparison to other disciplines. This paper shows that sociology too relies on objects of study that receive a disproportionate amount of attention and implicitly come to stand in for a specific class of objects. But, unlike other disciplines, sociology has no agreed language or theory to classify the discipline-specific objects that it studies, which hinders explicit reflection on the use of model systems across sociological subfields. The subfield of sociological theory uses model systems, but its specimens are not sociological objects. In contrast to other disciplines, which use model systems, specimens of sociological model systems usually do not travel. Because of this, the relationship between specimen and epistemic object is less standardised in sociology than in other disciplines. Sociology also encounters unique problems of access to model systems.
\end{abstract}

(C) 2012 Published by Elsevier B.V.

\section{Introduction}

Scholars in biology address general questions about life and disease by working with specific organisms selected for convenience and by convention. For every type of system biologists are interested in (such as a virus, an invertebrate organism, or a mammal), scientists tend to select particular ones for the purposes of research. Organisms selected for study, such as, most famously, fruit flies and mice, are called "model organisms" or "model systems". A model system links observations by different researchers in different sites; this allows a specific discovery to travel beyond its original site.

\footnotetext{
* Corresponding author.

E-mail addresses: m.krause@gold.ac.uk, bored.marxist@gmail.com (M. Krause), m.guggenheim@gold.ac.uk (M. Guggenheim).
}

0304-422X/\$ - see front matter (C) 2012 Published by Elsevier B.V. doi:10.1016/j.poetic.2012.02.007 
Do sociologists use model systems? If so, what are they, what work do they do for the discipline, and what are the consequences of their use? Discussions in the sociology of science about how model systems operate in biology and other disciplines (Creager et al., 2007b; Ensmenger, 2012; Poovey, 2001) provide an invitation to reflect on how similar devices operate in sociology and how they operate in sociology in comparison to other disciplines. Thinking about the biological use of model systems provides an analogous language with which to inquire into the ways sociology selects and rewards research objects. It can complement existing methodological and political reflection with a perspective from the sociology of science that is oriented towards research practice and the materiality of research objects and data. This inquiry can help us bring together discussions focused on the status of the classics in sociological theory (Connell, 1997, 2007; Seidman, 1994) with discussions on case selection and bias in other fields, such as urban sociology (Small, 2007). Indeed, following a wave of canon wars, we are now in a position to include contestations - as well as contestations that did not take place - within our object of analysis.

Since this is, to our knowledge, the first article to link sociology to the discussion on model systems, the form of this article is comparative and exploratory. Our intention is to give food for thought for subsequent, more detailed, empirical studies on the issues we raise here. We begin the paper by re-introducing the question and the comparative agenda of the paper. We then discuss the use of model systems in biology, develop the notion of the model system as a tool for comparative inquiry, and distinguish some of its dimensions. Next, we argue that sociology too relies on objects that receive an inordinate amount of attention and implicitly come to stand in for a specific class of objects.

We then discuss three aspects of how sociological model systems work and how they are different from model systems in other disciplines. First, unlike other disciplines, sociology has no agreed language or theory for what the objects (e.g. cities, professions, organisations) it is studying are kinds of, which hinders explicit reflection on the use of model systems across subfields. Second, sociological model systems are different from model systems in other disciplines in terms of how they circulate. The specimens of biological model systems are standardised in laboratories and circulate as genetically identical items. In sociology, the specimens of model systems themselves usually do not circulate. Neither Chicago, the French Revolution, a large hospital, nor a car factory can be stabilised and made to circulate. The fact that specimen of sociological model systems do not circulate has consequences, which we elaborate on: namely, problems for standardisation and for access to the research objects. Finally, we look at the selective forms of contestation about model systems. Contestation of model systems within sociology has focused almost exclusively on groups of people, while there has been very little focus on other categories, such as organisations or professions.

\section{Model-systems as fact-carriers: the ethnomethodological starting point}

If we start with the ethnomethodological insistence on the primacy of the observable situation - if only for strategic purposes - any form of social order that transcends local situations becomes a puzzle for further research (Garfinkel, 1991). "How is social order possible?" becomes a real question. In this view, circulation is not in tension with social order - conceived not as a normative concept, but in its most basic notion as a link across locales and a recognisable formbut it is, rather, its prerequisite: something must circulate for social order to exist.

The sociology of science has used this insistence on the local and the question "How do facts travel?" - based upon the strategic construction of an imagined basic unit of knowledge - to open up new empirical questions about knowledge production; asking that question has allowed it to 
cast a spotlight on the concrete practices involved in the production of knowledge and on the many steps involved in the creation and circulation of those practices (Howlett and Morgan, 2010; Latour and Woolgar, 1986). If we acknowledge that facts are always produced by a specific researcher in a specific locale, it becomes interesting to observe how facts that are produced in specific places are then transported to other places. They are usually attached to something in order to travel, such as an author's name, a journal, or a piece of technology. In this article, we discuss the way a specific carrier of facts operates in sociology, namely that of "model systems".

\section{Model systems in biology}

Let us first discuss the different elements of model system research in biology in order then to compare them to other disciplines. By convention, biologists focus on a few selected species to study the way organisms work:

Researchers selected this ... assortment from tens of millions of possibilities because they have common attributes as well as unique characteristics. They are practical: a model must be cheap and plentiful; be inexpensive to house; be straightforward to propagate; have short gestation periods that produce large numbers of offspring; be easy to manipulate in the lab; and boost a fairly small and (relatively) uncomplicated genome. This type of tractability is a feature of all well-used model systems (Bahls et al., 2003, quoted in Creager et al., 2007a, p. 7).

Several features of model system research are worth highlighting. First, model systems in biology focus research and pool resources. Model systems lead to a specific logic of research organisation: they concentrate a lot of work and researchers on one model system at the expense of other objects. Studying model systems is different from a logic of coverage ("I study $x$ because no one has studied $x$ before") that can be found in disciplines such as botany, history or anthropology. Contrary to model systems, in the logic of coverage, the fact that some research has been done on one case, one species or one tribe closes the case and drives other researchers to other cases, species or tribes. ${ }^{1}$ Model system research is also different from a logic of representativeness ("I study $x$ because it is representative of $y$ "). Model system research focuses on specific cases and it does not treat its specimens as direct representations of something else, but rather as opportunities for research, and it does not aim at universal laws (Creager et al., 2007b, p. 2).

Second, model systems are consciously manipulated and standardised - Kohler (1994) calls this 'organisms as technology' (p. 6). To turn individual specimens into instances of model systems, they need to be manipulated in such a way that they are stable in defined respects over different specimens. A drosophila needs to have known, defined, and stabilised genes and known and stabilised forms of behaviour. Only once specimens are thus rendered stable, can they be summarised as a model system. Because of this feature, model systems allow facts to travel Q2 across contexts by seemingly making context irrelevant (Amann, 1994; Leonelli, 2008). Third, standardisation of a model system is thought to render research comparable. Scientists working on a specific strain of drosophila can assume that there is no, or only very little, variance in the genotype and phenotype, and thus differences in research outcomes can be attributed to the

\footnotetext{
${ }^{1}$ This logic has been described memorably by Adam Kuper for Malinowskian anthropology in Cambridge, ca. 1960, as follows: 'An extreme but not exceptional view held that if a Malinowskian had worked in that region - or even in the same country - then it had been 'done' and one had best go somewhere else' (Kuper, 1999, p. 20).
} 
research rather than the organism. Fourth, this standardisation then allows research to be cumulative. Scientists working on the same strain of drosophila can integrate research results from another laboratory into their research. If one laboratory works on drosophila's vision, for example, this research can be directly integrated into the work of other laboratories on muscular movement in flight. For these reasons, model systems in biology can be explicitly enforced in the name of efficiency, as in the case of, for example, applications for research grants, which might be more easily awarded if a certain model system is used (Ankeny and Leonelli, 2011, p. 314).

The use of model systems also poses problems for research in biology. Because model systems are standardised stand-ins, it is unclear how they relate to other objects. First, it is unclear how they relate to their natural, unstabilised, non-standard relatives. Models systems are laboratory products. They are made stable and contextless by laboratory work. The removal of the stabilisation may also undo what is supposedly a feature of the organism, but what is in fact a feature of the stabilisation procedure. Second, as stand-ins, it is unclear how they relate to what they supposedly stand in for. Researchers may hope to find a gene for cancer in a mouse, but finding it is not a proof that the same mechanism works in humans too. Or, researchers may test a drug on a mouse that then proves fatal to humans in a trial (see Goodyear, 2006).

\section{Towards a comparative analysis of model systems}

The sociology, history and philosophy of science has drawn attention to the use of model systems in biology, and it has more recently also discussed the role of similar fact-carriers in other disciplines. Attention to model system research in biology has made it possible to see similarities between the natural sciences and what researchers in the humanities and interpretative social sciences already do, similarities that were previously obscured by an exclusive normative focus on law-seeking physics (Creager et al., 2007b; Forrester, 2007; Morgan, 2007; Ober, 2007). From the point of view of an empirical sociology of science, it is not enough to celebrate attention to particular cases, as some of the discussion in the philosophy of science has done (Creager et al., 2007a; Forrester, 1996). It is also important to pay close attention to research practice and the materiality of research objects and data that the original research on biology has collected and accept the invitation to observe other disciplines more closely and ask how facts travel in these fields in order to spot similarities, differences and contradictions (Amann, 1994; Ankeny and Leonelli, 2011; Kohler, 1994; Leonelli, 2008).

In what follows, we call a fact-carrier in other disciplines a model system if it serves as an object of study that pools resources and is used by convention to stand in for a more general class of epistemic objects. The knowledge gained through the analysis of model systems is supposed to hold also for other, not clearly specified cases. Our analytical notion of model system here subsumes what is also sometimes called "exemplars" (Kuhn, 1970, pp. 187-201), ${ }^{2}$ "paradigmatic cases", or "canonical cases". We group these together here initially, in order to then discuss similarities and differences in various disciplines with regards to the relationship between object studied and object known on a systematic basis, as discussed below. The concept of ideal type, as formulated by Max Weber in his essay “"Objectivity' in Social Science”, in

\footnotetext{
${ }^{2}$ Thomas Kuhn has devoted a section of the second edition of The Structure of Scientific Revolutions to the role of exemplars (1970, postscript, pp. 187-201). He was mostly interested in the role of exemplars for stabilising normal, paradigmatic science and how scientific revolutions regroup exemplars (p. 200). For example, sun, moon and mars were grouped together before Copernicus and what was learnt from one of these exemplars could be applied to the others, something which became impossible after Copernicus.
} 
Table 1

Comparison of the role of model systems across disciplines.

\begin{tabular}{|c|c|c|c|c|c|}
\hline Discipline & Specimen & Model system & $\begin{array}{l}\text { Kind of } \\
\text { system }\end{array}$ & $\begin{array}{l}\text { Most general } \\
\text { category }\end{array}$ & $\begin{array}{l}\text { General logic } \\
\text { of research }\end{array}$ \\
\hline $\begin{array}{l}\text { Biology (Ankeny and } \\
\quad \text { Leonelli, 2011) }\end{array}$ & $\begin{array}{l}\text { A particular } \\
\text { fruit fly }\end{array}$ & Fruit fly & Invertebrate & Organism & $\begin{array}{l}\text { Model systems } \\
\text { and logic of } \\
\text { coverage }\end{array}$ \\
\hline $\begin{array}{l}\text { Literary studies } \\
\quad \text { (Poovey, 2001) }\end{array}$ & $\begin{array}{l}\text { This copy of } \\
\text { Othello }\end{array}$ & Othello & Drama & Genre & $\begin{array}{l}\text { Model systems } \\
\text { and logic of } \\
\text { coverage }\end{array}$ \\
\hline Sociology & $\begin{array}{l}\text { Chicago studied } \\
\text { at a particular } \\
\text { time }\end{array}$ & Chicago & City & $\begin{array}{l}\text { Social form/ } \\
\text { social system }\end{array}$ & $\begin{array}{l}\text { Model systems } \\
\text { and laws, NO logic } \\
\text { of coverage }\end{array}$ \\
\hline $\begin{array}{l}\text { International Relations } \\
\quad \text { (Morgan, 2007) }\end{array}$ & - & $\begin{array}{l}\text { Prisoner's } \\
\text { dilemma }\end{array}$ & $\begin{array}{l}\text { Key } \\
\text { situations }\end{array}$ & $\begin{array}{l}\text { Decision-making } \\
\text { under conditions } \\
\text { of interdependence }\end{array}$ & $\begin{array}{l}\text { Model systems } \\
\text { and laws }\end{array}$ \\
\hline $\begin{array}{l}\text { Psychoanalysis } \\
\text { (Forrester, 1996, } \\
\text { 2007) }\end{array}$ & $\begin{array}{l}\text { Wolf Man, the } \\
\text { patient }\end{array}$ & $\begin{array}{l}\text { "Wolf Man" } \\
\text { as a written } \\
\text { case }\end{array}$ & Neurosis & Psyche & $\begin{array}{l}\text { Model systems } \\
\text { only }\end{array}$ \\
\hline $\begin{array}{l}\text { Political Theory } \\
\text { (Ober, 2007) }\end{array}$ & $\begin{array}{l}\text { Limited set of } \\
\text { sources on } \\
\text { "Athenian } \\
\text { democracy" }\end{array}$ & $\begin{array}{l}\text { Athenian } \\
\text { democracy }\end{array}$ & Democracy & Political system & Model systems \\
\hline
\end{tabular}

contrast, responds to a more specific methodological problem and is less useful for comparative analysis because of the normative orientation of its original formulation. ${ }^{3}$

In order to understand the role model systems play in sociology, it is important to draw on the full range of possible comparisons. Table 1 illustrates some of the analogies we are drawing on with different disciplines. We have selected a number of disciplines, which are discussed in the literature on model systems and where observers have pointed to fact-carriers similar to model systems in biology. Of course, our claims here are only preliminary and cannot replace detailed investigation of these cases. However, the table presents the current state of the discussion and it allows us to identify important dimensions of model systems and important axes for comparison. In each of the examples of model systems we distinguish between the specimen, that is, the physical object that is examined or studied, and the different levels of things it is meant to stand in for. Furthermore, the column titled "General Logic of Research" indicates how disciplines combine model system research with other forms of research, such as the "logic of coverage" discussed above or the "search for general laws".

We already discussed biology in detail in the preceding pages, so the first row should be selfexplanatory. It is important to note that biology is diverse, uses both field and laboratory science,

\footnotetext{
${ }^{3}$ The ideal type as conceived by Max Weber in his “"Objectivity' in Social Science” 'is formed by the one-sided accentuation of one or more points of view and by the synthesis of a great many diffuse, discrete, more or less present and occasionally absent concrete individual phenomena, which are arranged according to those one-sidedly emphasized viewpoints into a unified analytical construct' (2007[1904], p. 211). Weber here addresses the relationship between what in the table below is termed "specimen" and "kind of system" in a way that defends the usefulness of concept-formation. An ideal type has a very loose connection to empirical phenomena. Its quality and usefulness, but also its contested nature, derives precisely from its analytical and synthetic character, not from its close connection to some empirical specimen.
} 
and combines a logic of model systems with a logic of coverage. The second case, literary studies, has been discussed by Poovey (2001) in direct comparison to model systems in biology. She notes that genre fulfils a similar function in her discipline of literary studies as the one played by the notion of system in biology. Conceiving of a specific object as an organic whole aids in establishing a boundary for the discipline. It is the unity of genre that separates literary criticism from just any reading of a text and that separates critical expertise from ethical evaluation. Poovey notes that while biology has different kinds of systems that are of interest, such as cell, species, or ecosystem, literature has only genre. We might add, as Poovey does not, that the literary canon fulfils the same role as the agreement on specific model systems in biology. Literary scholars focus attention on specific works that are said to exemplify a genre. This means that Shakespeare's Othello is to drama as drosophila is to invertebrate organism and Keat's "Ode on a Grecian Urn" is to poem as mouse is to mammal. Like biology, literary studies complement the logic of genre with the logic of coverage. Key works from key authors, such as Shakespeare's dramas, give rise to an inordinate amount of research. At the same time, it is always possible to claim a contribution to the field by analysing obscure and previously unjustly neglected authors, a tendency memorably satirised in Lodge's Small World (2011[1984]).

Another case from the table, the Prisoner's dilemma within international relations as an example for thought experiments (Morgan, 2007), is a special one where specimen and model system coincide. Because thought experiments do not refer to an empirical case, they collapse the case with the model system. This also explains why they easily resort not to a logic of coverage to complement their research strategies, but to laws. The model system Prisoner's dilemma does not need to be stabilised and thus it has already a law-like form. Rather than being confused by the enormous amount of varying forms in the world, thought experiments dismiss these forms as irrelevant for the pursuit of a given problem.

Psychoanalysis is a case that has long interested philosophers of science who have wanted to rehabilitate attention to specific cases (Forrester, 1996). If we look closely and distinguish between specimen and model system, it emerges as a curious case. While reference to paradigmatic cases is clearly very important in orthodox psychoanalysis, only one researcher, (usually) Sigmund Freud, has access to specimens. For all later psychoanalysts, the specimen is accessible only through the case description provided by the actual therapist. Later psychoanalysts discuss theoretical differences with reference not to restudies of Wolf Man, but with reference to the interpretation of Freud's text on Wolf Man or his literary examples (Sealey, 2011). Psychoanalysis shifts very quickly to a literary relationship to its own canon; it is neither interested in a logic of coverage nor in laws. Although the large number of case descriptions within psychoanalysis would indicate a logic of coverage, such a strategy is not pursued, since each case is always reduced to the small number of guiding cases by the founders of the discipline. We could call this logic the "logic of application", where new research becomes relevant by a link to canonical description of previous research. This is also why psychoanalysis, unlike anthropology or biology lacks a "map" of cases in the world, in which white spots could be identified before undertaking research. Rather, an infinite number of possible new cases are always linked back to the central case.

\section{Model systems in sociology}

The question "Do sociologists use model systems?" can now be rephrased as "Do they use objects of research that receive a disproportionate amount of attention and implicitly come to stand as exemplars for a specific kind of object?'. Some subfields of sociology clearly do not use 
model systems. For example, survey research, demography and the quantitative sociology of stratification and education do not use model systems, but rather seek to establish general laws by working with datasets that are largely taken not as strategic cases but as representations of the real world.

On the other hand, we argue that some prominent subfields in sociology clearly do use model systems. Consider the following list of candidates for sociological model systems. We name the model system first and then the type of object it stands in for, followed by an indication of some exemplary and seminal literature that focuses on the model system (or literature that analyses the literature on the model system).

(1) Doctors (professions) (Abbott, 1988; Becker et al., 1977).

(2) Chicago (cities) (Park et al., 1925).

(3) African-Americans in cities (race) (DuBois, 1899; Wilson, 1980, 1987).

(4) The French Revolution (radical social change) (Sewell, 1985; Skocpol, 1979, 1985).

(5) The biological laboratory (the production of scientific knowledge) (Latour and Woolgar, 1986; Knorr Cetina, 1981).

(6) The Scientific Revolution (the relationship of science and society) (Merton, 1938).

(7) English working class (class formation in capitalism) (Calhoun, 1982; Marx, 2007[1857]; Thompson, 1964).

(8) Car industry (organisation, work) (Rot, 2006).

(9) Women (gender studies).

(10) Juvenile petty criminals (the sociology of law, criminology) (Cohen, 1955; Shaw et al., 1938).

(11) Marx, Durkheim, Weber (theory, history of sociology).

(12) High art (culture) (Becker et al., 1977; White and White, 1993).

There are important differences in what kind of objects these model systems are and how specimen, object and general category relate; we discuss some of these differences below. But there are a few general points we can make. First, there appears to be some relationship between model systems and subfields as they exist today: some subfields use model systems and indeed model systems may help cement their status as subfields. Studies about doctors are foundational for the sociology of professions, studies about Chicago are foundational to urban sociology and urban ethnography, and studies of the French Revolution are central to comparative-historical sociology. Criminology has focused intensely on petty criminals and has, as a result, relatively neglected other forms of criminals. Renault has served as a model system for the sociology of work done in France (Rot, 2006). Sociological theory is still prominently shaped by a consideration and reconsideration of the classic texts as model systems for sociological thought. The sociology of culture, while very diverse in the topics it covers, is shaped by two model systems. For some of the work in this field, the production of high art was foundational. It has also been suggested that the field as a broader area of investigation implicitly uses religion as its model case for culture in general - consider the work of both Weber and Durkheim - and that this legacy has shaped it in unacknowledged ways, by an inherited opposition of culture to rationality for example (Altinordu, 2009).

Second, in each of these subfields, classic works on the model system are central to teaching and to theoretical debate and model systems continue to concentrate a disproportionate amount of resources in terms of scholarly time and attention. A reinterpretation of a classic case can garner significant rewards in terms of attention and recognition, while it is more difficult for work on an odd or unrecognisable case to be accepted as theoretically relevant. 
Third, model systems help to integrate micro- and macro-sociology or different theoretical strands within one object. All model systems in sociology reproduce within themselves the universe of approaches within sociology (see Abbott's (2001) book Chaos of Disciplines). Thus within urban sociology, organisational sociology or the sociology of radical social change, an integration and dispute between Parsonsian and Foucauldian or between interactionist and structuralist approaches may happen.

Fourth, there is a complementary logic that values research on neglected cases. However, these tend to be reproductions of the model systems for new and obscure cases, a logic we call "logic of application": what is found to be true for juvenile delinquents in Chicago is also found to be true with some divergences in Denver, and what is found to hold for doctors is found to hold for priests as well. A version of this logic is observed by Connell (1997) as the phenomenon " $\mathrm{X}$ in Australia" (p. 81). Researchers in Australia felt compelled to re-do canonical studies in other settings: "The task of the Australian sociologist was to apply the metropolitan research technique, demonstrate that the phenomenon also existed in Australia, and say empirically what form it took here" (ibid.).

There is no logic of discovery attached to research on non-canonical cases: there is no prize to be won for having done research in a remote village of Arkansas, such as there is for having found a rare species in biology, a remote tribe in anthropology or an unknown language in linguistics. The map of sociology does not define known and unknown points in a space; rather it identifies cases in terms of their relative importance with regard to model systems.

\section{The missing systematics of sociological objects}

In literature, the notion of genre provides a general category for what the canonical cases are cases of in the way systems theory does for biology. Shakespeare's Othello is a drama, drama is a genre. The fruitfly is an invertebrate, the invertebrate is a system. There is less consensus in sociology as to what kinds of things the objects that it studies are (professions, cities, radical social change). "Social forms" or indeed Durkheim's notion of "social fact" might be the most plausible candidates for establishing categorisation. If Matthew Arnold established organic unity within a form as the basis for genre theory and thereby distinguished literary criticism from amateur reading, as Poovey (2001) discusses, the parallels to Durkheim's project are striking. Durkheim is explicitly concerned with founding sociology as a discipline and he does so by establishing social facts as a thing sui generis and making them available for sociologists to study (Durkheim, 1982). Sociologists still seek to distinguish their own interpretations from those of journalists and popularisers in the name of a specialised language about the nature of social forms.

However, while such a project marked the beginning of sociology, there is no consensus in contemporary sociology about how to think about these objects of sociological study and their shared characteristics. Sociology has no language for describing its central overarching metaconcepts and it has no theory of how these concepts relate to each other. Although terms such as interaction, organisation, professions, science, religion, or culture are widely used to define internal specialisations, it is the model systems themselves that describe these terms rather than a theory that puts them in a relationship vis-à-vis each other. For example, there is no theory of how science relates to professions and organisations (but see Abbott, 2005; Stichweh, 1994).

The exception in terms of an explicit theorisation of what sociological objects uniquely share and also of different sociological objects, the one theory that delivers a sociological systematics, is the systems theory of Niklas Luhmann, which remains at the periphery of Anglo-American 
sociology. Luhmann provides a theoretical language that breaks radically with common sense, thus pursuing a programme of disciplinary autonomy. He offers a framework for relating sociological objects vis-à-vis each other. In Luhmannian systems theory there are different levels of systems - functional systems, organisations and interaction systems (Luhmann, 1975, 1982 [especially Chapter 4], 1997) - each of which is defined by a different mode of communication. These different forms can occur within each other - professions can be more or less organised, functionally differentiated communication routinely occurs within interaction, etc. - but each of these are accounted for in theoretical terms and each of them can be identified as empirically relevant data. In fact, the very raison d'être of systems theory as an explicit theory of society (and not a theory of a specific subsystem or field) could be said to clarify these relationships for sociology and society. At the same time, the very fragmentation and lack of a theory of society in Anglo-American sociology makes systems theory today so hard to understand in this context.

As we have outlined above, one reason for the use of model systems is that they allow to pool research and therefore make it comparable and possible to integrate various research strands (Ankeny and Leonelli, 2011, p. 314). Because so many biologists work on mice, it is possible for one research group that works on behavioural experiments to use the results of another research group that works on genetics. This is possible because there is a general theory of how different levels or elements within a discipline relate to each other and the model system acts as a place where these different strands come together. There is a shared systematics between subfields (such as genetics and behavioural biology), which allows various research results to be related to each other.

Because such a systematics is less clear in sociology, the possible gains from model systems are more limited. The lack of an accepted systematics outside the community of scholars in the tradition of systems theory and a theorisation of how different levels of society interrelate, makes it difficult to reflect on the selection of model systems across subfields and to integrate findings from different specialisations. Note that in the table above, there is no model organism that overarches several subfields. Car factories are model systems for organisational sociology only, and not for religious sociology or the sociology of ethnicity (although many questions within these fields could be studied in car factories).

The subfield of sociological theory emerges as an odd case in this reflection - it has a high agreement on the model systems selected for study, the theoretical canon, yet the units of this canon are people and texts and thus not exemplars of sociological objects in any theoretical language. Durkheim, Marx, and Weber are not social forms in any possible conceptualisation of what a social form is. In sociological theory, the canon thus operates like a literary canon, but without a theory of genre or a theory of how to work with texts. To some extent, the circulation of facts via theorists is in tension with circulation via sociological model systems. When certain authors are designated as theorists, their data becomes dissociated from the case and gets applied as theory to other cases. For example, actor-network theory (ANT) initially started as a description of biological laboratories, but its language later expanded to describe other objects in the world, which in turn led researchers to designate these objects as laboratories (see Guggenheim, forthcoming).

\section{Problems of circulation}

Let us note some other differences between sociological model systems and biological model systems. As discussed in our definition of the model system in general and shown by Kohler (1994) and Amann (1994), model systems are stabilised in laboratories and circulate as 
genetically identical items. In sociology, due to the nature of the epistemic objects, the model systems themselves usually do not circulate. Neither Chicago, the French Revolution, a large hospital, nor a car factory can be stabilised and made to circulate. Sociologists do not usually attempt to disconnect the epistemological objects from their (physical and immobile) context, also because such a disconnection, a laboratisation of the object, would appear to threaten for many the interest of the object (see Guggenheim, forthcoming). Although there are both old and more recent attempts to call sociological fields laboratories, which would imply control of objects, sociologists rarely attempt such control. Sociologists believe that the situatedness of the epistemic object forms precisely its value. In what follows we discuss two problems that result from the fact that model systems do not circulate: Sociological model systems are not standardised and are not easily accessible.

\subsection{Degrees of standardisation}

Let us again examine the relationship between specimen and model system in different disciplines. A specimen is the actual physical copy in front of the researcher, a model system is the category that is studied through this. It is important to note here that researchers in some disciplines go through a lot of trouble to make sure variation among specimens is controlled. Consider the cases of biology and literary studies. Biologists do not all study the same animalsay, drosophila- they try to control the variation among individual drosophilae studied and they study similar drosophilae. They do not circulate the actual animal, but they try to produce identical copies and circulate those. They isolate the object from its context - a 'special kind of domestication', as Kohler (1994, p. 9) calls it. They usually study genetically identical drosophila so that they know the variation observed is not due to genetic differences of the object of study, or they study genetically different drosophila, but then they know about the differences between the different genotypes.

The equivalent for literary studies is the physical copy of James Joyce's Ulysses, for instance, that a scholar is working with. Again, stabilisation happens through copying and multiplying the research objects. Not all editions of the book are the same and indeed scholars pay much attention to the differences between different editions in order to find out who is studying "the real" Joyce, but also to make clear which differences of interpretation are owed to different versions of the text (e.g. Rossman, 1988). Translations add another level of variation and issues of translation are discussed as problems of research. But standard editions of texts go very far in making sure that research objects are identical and deviations can be identified and named.

Some model systems lack an empirical referent and thus standardisation is less of a concern. The prisoner's dilemma or Galileo's thought experiments with falling bodies exist only as mental projections and there is nothing "out there" in the world that could vary (McAllister, 2005; Sorensen, 1999).

In sociology, the model systems are conceived of as empirical objects but the specimens do not travel and are not copied. Because of this, the objects of research are less standardised than in other disciplines and different research projects on different specimens of the same model system are not easily comparable. This creates problems for the accumulation of knowledge, which is the implied justification for the use of model systems. Consider the case of Chicago. It is true that the agreement among urban sociologists to focus on Chicago to some extent ensures comparability even though Chicago is not representative of US cities, let alone cities in general. Among sociological model systems Chicago is relatively stable. Unlike a profession, for example, it is "locked in place", and to a large extent geographic variation among specimens of the model 
system is excluded. But even though Chicago as a model system is relatively stable, variation due to time cannot be excluded and the variation of what one could look at, even if one studied it at the same time - the informants that the researcher meets, the data considered - would be greater than in disciplines where standardised copies circulate. The Chicago of the 1980 s may be very different from the Chicago of the 1990s. In the same way as one cannot swim in the same river twice, as the saying goes, no two people study the same Chicago, and no individual studies Chicago twice. In another example, different researchers in the sociology of professions study different doctors and no sociologist is actively involved in manipulating doctors for the purposes of standardisation for research. Hospitals, for example, are not passed on among researchers; indeed access to an organisation is often so difficult that repeated research within a single organisation is unlikely. A researcher who has secured access is likely to remain the only researcher within any given organisation.

The fact that in sociology, classifications are often part of the object to be studied, what Anthony Giddens (1993) calls 'double hermeneutics', is one aspect of the problem of standardisation. Consider the case of petty criminals for criminology. Petty criminals represent for sociology the relationship between the legal system and society (as opposed to, say, administrative law or financial crimes, both understudied). But within the study of criminality, the notion of what petty criminality as an object is, is vastly different in different places of study, simply because the criminals in one place are different from those in another. Moreover, the notion of the petty criminal itself is not standardised within sociology since it is not a sociological notion, but a legal notion that is dependent on national and regional legal definitions particular also to different historical circumstances. A comparative study of petty criminality has to grapple with the problem that the systematics of the object is unstable over the cases and renders a comparison difficult.

In some cases, sociologists can try to use attempts to standardise by social actors in the real world as an opportunity to ensure comparability. The more control social actors have over designing something, the more comparable the resulting objects are. In the French sociology of work and organisations a large number of studies were conducted within the factories of one a single manufacturer, namely Renault; here this fact was used to write a history of changing working conditions within the automotive factory (see Perriaux, 1998; Rot, 2006). In cases where blueprints do travel, such as for organisations or products, they have allowed comparative study (Casper and Hanckj, 1999; Grandin, 2010). The problem of standardisation occurs in specific ways when the object is historical, as in the case of the French Revolution, Greek democracy, or, to a lesser degree, the Holocaust. In these cases, standardisation is possible to the extent that a defined set of sources is equally available to researchers. The fewer the sources, the more standardised and stabilised the model system. Standardisation and stabilisation in these cases is less a result of a research practice, but of historical processes, in which only a small set of sources survive. Here, sociology approximates literary studies in relation to its objects. Challenges to standardisation then occur when new sources appear or when scholars widen the pool of sources; examples include the interpretation of French history from the perspective of the provinces (Weber, 1979) or from women's point of view (Scott, 1986).

Here again sociological theory is a special case. In this case specimens do travel - in the form of, for example, the physical copies of Durkheim's The Elementary Forms of Religious Life or Weber's Protestant Ethic. The specimens here are highly standardised, but this is partly because they have become disconnected from the sociological object they refer to. In social theory there is a text-based canon and here sociology approaches the degree of standardisation common in literary studies (with similar debates on the importance of different parts of an author's work, but 
with less attention to editorial details; consider for example the debates about different parts of Marx's opus and their implications for sociology (Althusser and Balibar, 1997; Musto, 2008). A "theoretical" text within sociology does not necessarily contain less empirical data than "empirical" texts. Theoretical debates are precisely theoretical because they do not go back to the context of the empirical material within these texts, but treat them as self-contained texts. Theory texts circulate in identical forms as literary texts, but there is no theory of their relationship to sociological objects, and, as this is not literary studies, also no theory of the text as text or its relationship to the author (cf. Cohen, 1999 on Latour and Koschorke, 1999 on Luhmann).

\subsection{Problems of access}

Because model systems exist in sociology, some objects receive a disproportionate amount of attention and are implicitly assumed to stand in for other similar phenomena. But these model systems do not, themselves, circulate. This means that researchers have unequal access to model systems, and thereby unequal access to the possibility of producing knowledge that is thought to be relevant and cumulative. The problem occurs on the level of regions and countries and is built into the very foundations of the discipline. The concept of modernity has been central to sociology and, as Chakrabarty (2000) has argued, Europe might have been the unacknowledged model system for "modernity". France and Germany have served as model systems for Europe. The very history of the discipline is based on the study of very small set of states (USA, France, Germany, and Italy) (see also Wagner et al., 1991), which means that nationally specific model systems are imposed on those scholars who do not live in these few countries. Those who live in the global south, as well as in smaller European nations or Australia have a harder time contributing to the seemingly cumulative research on model systems for societies.

An interesting case for this is the role of specific cities in urban sociology. As Thomas Gieryn has shown, in early American sociology, Chicago sociologists managed to turn their field, the city of Chicago, into the canonical research setting for urban sociology and the nascent discipline as a whole (Gieryn, 2006). What was explored in Chicago as a specific field site became, through what Gieryn calls the 'lab-field shuttle,' general knowledge about cities. Whoever worked at the University of Chicago in these first decades of the twentieth century had the advantage of adding to a seemingly cumulative research enterprise that collected knowledge about a specific field site - Chicago - that was a stand in for "city" that was a stand in for "modern society", in a way in which, for example, Heidelberg and Freiburg in Germany were not. This process was further intensified by the canonisation of the Chicago school as the founding place for American sociology. Knowledge about "the city" in the early twentieth century was difficult to achieve in Denver, Freiburg or Maputo, because these places were not specimens of the model system and doing research in Chicago was difficult and costly for researchers not based there.

With time, it became clear that Chicago was but one city among others, a city with a particular structure that is not a model system for cities per se. Moreover, since the 1980s, it appears that Chicago represented a model system that is no longer representative for the problems that American cities face. Chicago was the dense city of the twentieth century that exposed the frantic pace of industrial and financial centres and that drew a massive influx of migrants to the jobs these industries offered. At the end of the century, Chicago was an outdated model and Los Angeles became a new model system (see Dear and Dishman, 2001; Judd and Simpson, 2011). The city of the late twentieth century was not a dense and hectic amalgam, but sprawl, a vast carpet of uniform and indistinct buildings without a centre and connected by endless highways. Again, the 
ascent of these new model systems was proposed by scholars at universities located in the model system itself who had easy access to this place, who could study it and highlight its peculiarities and who could gain reputation for their universities by establishing this new model system there. Today, Los Angeles, in turn, has lost its status as model system and it is the fast-growing cities of the south, such as Lagos, Johannesburg, Istanbul, Cairo, Hong Kong and Shanghai that are now replacing it. However, none of these cities seems to be considered as a model system, and it is typical for the situation that they are rather lumped together into one category: "mega-cities of the south".

However, while the model systems seem to be changing, the academic spaces of control over these systems do not, or at least not with the same tightness as in the case of Chicago and Los Angeles. Researchers who do work on the new model systems often come from far away and the rise of these model systems owes more to the universities based in the old model systems - Chicago, London and Los Angeles. Only with the shift of the model system to the south has the link between institutional location and object of research been broken. One reason for this is that those living and researching in the new model systems do not have the institutional power to claim them as their own, while those who have institutional power are now able to do research in far-away model systems as international travel has become fast and cheap. The case for model systems based on textual sources and library research is somewhat different. Access to the sources on the French Revolution or the Holocaust is not equally distributed, but it is essentially similar to cases in history and literature. Sociological theory, again, comes closest to the literary canon in that selection is biased but access is, in material terms, relatively easy.

\section{The selective forms of contestation about model systems}

An important part of examining model systems, is to observe the ways in which they are thought about and fought over. Future research could systematically address how different disciplines observe themselves in this regard. We cannot fully do justice to this agenda here but we can bring together what is known about different cases and offer some initial observations about sociology.

The classic case of contestation about model systems is the canon wars in literary studies. In literature, there has been an intense struggle around which novels come to represent specific genres. Critics have asked if the established canon is representative of literary production and of wider society and have pushed for the inclusion in it of popular culture as well as marginalised voices, such as those of women and ethnic minorities. One the one hand, literary scholars have insisted on a broader range of model systems, both in terms of which books to select for study and which kinds of genres to include. In a stronger stance, critics have questioned the pooling of resources associated with the use of model systems as well as the relevance of the term genre altogether. ${ }^{4}$ This could be considered a rebellion against the logic of model systems, either in the name of a traditional logic of coverage or a poststructuralist version of it. In sociology, reflection on the use of model systems does not span across subfields, is uneven within different subfields and selects specific forms of reflexivity over others that would also be possible.

\footnotetext{
${ }^{4}$ Guillory (1993) has analysed this as a displacement of social struggles into literature just at the time when the elites abandon classical liberal education as an important arena of social reproduction.
} 
In sociology, the most intense contestation has happened in sociological theory where the use of model systems is most explicit. Sociology has had its own canon wars where sociologists have fought to include different kinds of people such as women, people of colour and people from the global south as theorists (Connell, 1997, 2007; Seidman, 1994). We have said that what is odd about the case of sociological theory is that the model systems chosen here are not sociological phenomena at all, but rather individual people.

We have also seen contestation of other aspects of the use of model systems. We have witnessed a rebellion within the discipline against the white man as a model system for person, against the white middle-class woman as a model system for women (Hooks, 1981) and against the nuclear family as the model system for studying the family (Stacey, 1998). Chakrabarty (2000) has made the case for provincialising Europe; that is, he has criticised the social sciences for their implicit use of Europe as a model system for modernity or more generally, society. These interventions seem to be most effective when they are linked with domestic categories of political contestation, with the unit "people" or "groups of people", but in doing so they have used the categories of social and political struggles for inclusion, rather than sociological concepts. But even in sociology, which is often said to be closer to political struggles than the humanities or the sciences, and for good reason, the metaphors of excluded people and groups do not fully cover the range of possible debates. Neglected cities, professions, organisations or crimes, for example, do not speak back as easily and scholars seem not to speak up in the same way on their behalf. The city of Cosenza, priests, vending machine operators or financial fraudsters do not have a lobby for inclusion in the same way as women or ethnic minorities do.

In addition to neglected cases, whole social forms can also be neglected as the result of the missing taxonomy discussed above. The lack of a taxonomy implies that sociology does not have a clear idea how the objects it researches relate to the universe of possible objects. The contestation of model systems depends then on individual scholars or groups of scholars who make it their case to dethrone a model system. However, because of personal and political dynamics, this rarely happens with a view of the universe of possible cases in mind. The tendency to reflect via categories of political contestation is reinforced through the institutions of human subjects review systems that are taken from medical research (see also Epstein, 2007). Procedures for the approval of research with human subjects ask for the justification of gender or race-specific sampling, but do not engage with case selection in general. One does not need to justify why medium-sized towns or certain professions, for instance, are not included in a study. We are now in an odd situation where no one explicitly makes the case for a greater efficiency of model systems vis-à-vis the logic of coverage or tries to explicitly exploit the advantages this can bring, while an implicit understanding about what are important cases and what are odd and unique cases continue to make it harder to do research on subjects like medium-sized cities, small European countries, small professions or unusual forms of crimes.

\section{Conclusion}

We have argued that in sociology, as in some other disciplines, facts travel via model systems. An observation in a specific setting is aided when it gets attached to an established discussion on what is implicitly agreed to be an important case. Sociology relies on objects of study that receive a disproportionate amount of attention and implicitly come to stand as exemplars for a specific kind of object. But unlike biology and literary studies, sociology has 
no unified language for the kinds of things it is studying. Because specimens of sociological model systems themselves do not travel, the relationship between specimen and epistemic object is less standardised than in biology and literature and sociology encounters unique problems of access to model systems; its forms of contestation draw on everyday categories, rather than on specifically sociological terms.

In order to be able to better reflect on the implications of our choice of particular model systems, we might first have to embrace the idea of a range of specifically sociological objects (other than people or groups of people) that we study more explicitly - whether we call them social forms, networks or systems. Empirically, taking the question "How do facts travel?" seriously opens up further questions. The agenda for future research is, first, to do more empirical work on the various model systems of sociology and other disciplines, with attention to the relationship between specimen and epistemic object and attention to modes of reflection on model systems. Second, the comparative task would be to contrast across disciplines how different kinds of carriers of facts, such as authors' careers, theories, model systems, institutional prestige, periods, and subfields interact and what boundaries they encounter.

\section{Uncited reference}

Q3

Turner (2000).

\section{Acknowledgements}

Stefan Bargheer, Craig Calhoun, Will Davies, Oskar Kelly, Linsey McGoey, Jörg Potthast, two anonymous reviewers, the journal editors and the participants of the "Cultures of Circulation" workshop at Carleton University in April 2011 provided helpful comments on earlier versions of the paper. The authors would like to thank Melissa Aronczyk and Ailsa Craig for the initiative that led to this paper and very helpful comments.

\section{References}

Abbott, A.D., 1988. The System of Professions: An Essay on the Division of Expert Labor. University of Chicago Press, Chicago.

Abbott, A.D., 2001. The Chaos of Disciplines. University of Chicago Press, Chicago.

Abbott, A.D., 2005. Linked ecologies: states and universities as environments for professions. Sociological Theory 23 (3), 245-274.

Althusser, L., Balibar, E., 1997. Reading Capital. Vero, London.

Altinordu, A., 2009. Ideology, identity, and religious politics. In: ASA Junior Theorists Symposium, University of California, Berkeley, August 7.

Amann, K., 1994. Menschen, Mäuse und Fliegen: Eine wissenssoziologische Analyse der Transformation von Organismen in epistemische Objekte. Zeitschrift fuer Soziologie 23 (1), 22-40.

Ankeny, R.A., Leonelli, S., 2011. What's so special about model organisms? Studies in History and Philosophy of Science Part A 41 (1), 313-323.

Becker, H.S., et al., 1977. Boys in White: Student Culture in Medical School. Transaction Publishers, New York.

Calhoun, C.J., 1982. The Question of Class Struggle: Social Foundations of Popular Radicalism during the Industrial Revolution. University of Chicago Press, Chicago.

Casper, S., Hanckj, B., 1999. Global quality norms within national production regimes: ISO 9000 standards in the French and German car industries. Organization Studies 20 (6), 961-985.

Chakrabarty, S.D., 2000. Provincializing Europe: Post-Colonial Thought and Historical Difference. Princeton University Press, Princeton, NJ.

Cohen, A., 1955. Delinquent Boys: The Culture of the Gang. Free Press, Glencoe, IL. 
Cohen, S., 1999. Reading science studies writing. In: Biagioli, M. (Ed.), The Science Studies Reader. Routledge, New York, pp. 84-94.

Connell, R.W., 1997. Why is classical theory classical? American Journal of Sociology 102 (6), 1511-1557.

Connell, R., 2007. Southern Theory: The Global Dynamics of Knowledge in Social Science. Polity Press, Cambridge, UK.

Creager, A.N.H., Lunbeck, E., Wise, M.N., 2007a. Introduction. In: Creager, A.N.H., Lunbeck, E., Wise, M.N. (Eds.), Science without Laws: Model Systems, Cases, Exemplary Narratives. Duke University Press, Chapel Hill, pp. 1-20.

Creager, A.N.H., Lunbeck, E., Wise, M.N., 2007b. Science Without Laws: Model Systems, Cases, Exemplary Narratives. Duke University Press, Chapel Hill.

Dear, M., Dishman, J.D. (Eds.), 2001. From Chicago to L.A.: Making Sense of Urban Theory. Sage Publications, Thousand Oaks, CA.

DuBois, W.E.B., 1899. The Philadelphia Negro: A Social Study. University of Pennsylvania Press, Philadelphia.

Durkheim, E., 1982. The Rules of Sociological Method. Free Press, New York.

Ensmenger, N., 2012. Is chess the drosophila of AI? A social history of an algorithm. Social Studies of Science 42 (1), 5-130.

Epstein, S., 2007. Inclusion: The Politics of Difference in Medical Research. University of Chicago Press, Chicago.

Forrester, J., 1996. If p, then what? Thinking in cases. History of the Human Sciences 9 (3), 1-25.

Forrester, J., 2007. The psychoanalytic case: voyeurism, ethics, and epistemology in Robert Stoller's Sexual Excitement. In: Creager, A.N.H., Lunbeck, E., Wise, M.N. (Eds.), Science without Laws: Model Systems, Cases, Exemplary Narratives. Duke University Press, Chapel Hill, pp. 189-212.

Garfinkel, H., 1991. Respecification: evidence for locally produced, naturally accountable phenomena of order, logic, reason, meaning, method, etc., in and as of the essential haecceity of immortal ordinary society (I) — an announcement of studies. In: Button, G. (Ed.), Ethnomethodology and the Human Sciences. Cambridge University Press, Cambridge, UK, pp. 10-19.

Giddens, A., 1993. New Rules of Sociological Method: A Positive Critique of Interpretative Sociologies. Stanford University Press, Stanford, CA.

Gieryn, T.F., 2006. City as truth-spot: laboratories and field-sites in urban studies. Social Studies of Science 36 (1), 5-38.

Goodyear, M., 2006. Learning from the TGN1412 trial. British Medical Journal 332 (7543), 677-678.

Grandin, G., 2010. Fordlandia: The Rise and Fall of Henry Ford's Forgotten Jungle City. Macmillan, Oxford, UK.

Q4 Guggenheim, M. Laboratizing and delaboratizing the world: changing sociological concepts for places of knowledge production. History of the Human Sciences, forthcoming.

Guillory, J., 1993. Cultural Capital: The Problem of Literary Canon formation. University of Chicago Press, Chicago.

Hooks, b., 1981. Ain't I a Woman: Black Women and Feminism. South End Press, Boston.

Howlett, P., Morgan, M.S., 2010. How Well Do Facts Travel? The Dissemination of Reliable Knowledge. Cambridge University Press, Cambridge, UK.

Judd, D.R., Simpson, D. (Eds.), 2011. The City, Revisited: Urban theory from Chicago. University of Minnesota Press, Minneapolis, Los Angeles, and New York.

Knorr Cetina, K., 1981. The Manufacture of Knowledge: An Essay on the Constructivist and Contextual Nature of Science. Pergamon Press, Oxford.

Kohler, R., 1994. Lords of the Fly: Drosophila Genetics and the Experimental Life. University of Chicago Press, Chicago.

Koschorke, A., 1999. Die Grenzen des Systems und die Rhetorik der Systemtheorie. In: Koschorke, A., Vismann, C. (Eds.), Widerstände der Systemtheorie: kulturtheoretische Analysen zum Werk von Niklas Luhmann. Akademie Verlag, Berlin, pp. 49-62.

Kuhn, T.S., 1970. The structure of scientific revolutions. In: International Encyclopedia of Unified Science, vol. 2, 2 nd ed. University of Chicago Press, Chicago.

Kuper, A., 1999. Postmodernism, Cambridge and the great Kalahari debate. In: Kuper, A. (Ed.), Among the Anthropologists: History and Context in Anthropology. Athlone, London, pp. 15-35.

Latour, B., Woolgar, S., 1986. Laboratory Life: The Construction of Scientific Facts. Princeton University Press, Princeton, NJ.

Leonelli, S., 2008. Circulating evidence across research contexts: the locality of data and claims in model organism biology. LSE Working Papers on the Nature of Evidence: How Well Do 'Facts' Travel? No. 25.

Lodge, D., 2011[1984]. Small World. Vintage, London.

Luhmann, N., 1975. Interaktion, organisation, gesellschaft. In: Soziologische Aufklärung 2, Westdeutscher Verlag, Opladen, pp. 9-20.

Luhmann, N., 1982. The Differentiation of Society. Columbia University Press, New York.

Please cite this article in press as: Krause M., Guggenheim, M., How facts travel: The model systems of sociology. Poetics (2012), doi:10.1016/j.poetic.2012.02.007 
Luhmann, N., 1997. Die Gesellschaft der Gesellschaft. Suhrkamp, Frankfurt.

Marx, K., 2007[1857]. Capital: A Critique of Political Economy, Volume I, Part I: The Process of Capitalist Production. Cosimo Inc., New York.

McAllister, J.W., 2005. The virtual laboratory: thought experiments in seventeenth-century mechanics. In: Schramm, H., Schwarte, L., Lazardzig, J. (Eds.), Collection, Laboratory, Theater: Scenes of Knowledge in the 17th Century. Walter de Gruyter, Berlin, pp. 35-56.

Merton, R.K., 1938. Science, Technology and Society in 17th Century England. St. Catherine Press, Bruges, Belgium. Morgan, M.S., 2007. The curious case of the prisoner's dilemma: model situation? Exemplary narrative?. In: Creager, A.N.H., Lunbeck, E., Wise, M.N. (Eds.), Science Without Laws: Model Systems, Cases, Exemplary Marratives. Duke University Press, Chapel Hill, pp. 157-186.

Musto, M., 2008. Karl Marx's Grundrisse: Foundations of the Critique of Political Economy 150 Years Later. Taylor and Francis, London.

Ober, J., 2007. Democratic Athens as an experimental system: history and the project of political theory. In: Creager, A.N.H., Lunbeck, E., Wise, M.N. (Eds.), Science Without Laws: Model Systems, Cases, Exemplary Narratives. Duke University Press, Chapel Hill, pp. 225-243.

Park, R., et al., 1925. The City. Chicago University Press, Chicago.

Perriaux, A.-S., 1998. Renault et les sciences sociales, 1948-1991. Seli Arslan, Paris.

Poovey, M., 2001. The model system of contemporary literary criticism. Critical Inquiry 27, 408-438.

Rossman, C., 1988. The new 'Ulysses': the hidden controversy. The New York Review of Books 35, 53-58.

Rot, G., 2006. Sociologie de l'atelier: Renault, le travail ouvrier et le sociologue. In: Octarès, Toulouse, France.

Scott, J.W., 1986. Gender: a useful category of historical analysis. The American Historical Review 91 (5), 1053-1075.

Sealey, A., 2011. The strange case of the Freudian case history: the role of long case histories in the development of psychoanalysis. History of the Human Sciences 24 (1), 36-50.

Seidman, S., 1994. The Postmodern Turn: New Perspectives on Social Theory. Cambridge University Press, Cambridge.

Sewell, W.H., 1985. Ideologies and social revolutions: reflections on the French case. Journal of Modern History 57 (1), 57-85.

Shaw, C., et al., 1938. Brothers in Crime. University of Chicago Press, Chicago.

Skocpol, T., 1979. States and Social Revolutions: A Comparative Analysis of France, Russia, and China. Cambridge University Press, Cambridge.

Skocpol, T., 1985. Cultural idioms and political ideologies in the revolutionary reconstruction of state power: a rejoinder to Sewell. Journal of Modern History 57 (1), 86-96.

Small, M.L., 2007. Is there such a thing as 'The Ghetto'? The perils of assuming that the South Side of Chicago represents poor black neighborhoods. City 11 (3), 413-421.

Sorensen, R.A., 1999. Thought Experiments. Oxford University Press, Oxford.

Stacey, J., 1998. Brave New Families: Stories of Domestic Upheaval in Late-Twentieth-Century America. University of California Press, Berkeley, CA.

Stichweh, R., 1994. Professionen und Disziplin: Formen der Differenzierung zweier Systeme beruflichen Handelns in modernen Gesellschaften. In: Stichweh, R. (Ed.), Wissenschaft, Universität, Professionen. Suhrkamp, Frankfurt am Main, pp. 278-336.

Thompson, E.P., 1964. The Making of the English Working Class. Pantheon Books, New York.

Turner, S., 2000. What are disciplines? And how is interdisciplinarity different?. In: Weingart, P., Stehr, N. (Eds.), Practising Interdisciplinarity. University of Toronto Press, Toronto, pp. 46-65.

Wagner, P., Wittrock, B., Whitley, R. (Eds.), 1991. Discourses on Society. The Shaping of the Social Science Disciplines. Kluwer Academic Publishers, Dordrecht, The Netherlands.

Weber, E., 1979. Peasants into Frenchmen: The Modernization of Rural France, 1870-1914. Stanford University Press, Stanford.

Weber, M., 2007[1904]. "Objectivity" in social science. In: Calhoun, C., et al. (Eds.), Classical Sociological Theory. Wiley-Blackwell, Malden, MA, pp. 211-217.

White, H.C., White, C.A., 1993. Canvases and Careers: Institutional Change in the French Painting World. University of Chicago Press, Chicago.

Wilson, W.J., 1980. The Declining Significance of Race: Blacks and Changing American Institutions. University of Chicago Press, Chicago.

Wilson, W.J., 1987. The Truly Disadvantaged: The Inner City, the Underclass, and Public Policy. University of Chicago Press, Chicago. 
Monika Krause is a Lecturer in Sociology at Goldsmiths College, London. She is interested in comparative questions about fields of specialised practice and professions. She has recently published "Accounting for state intervention. The social histories of beneficiaries", in Qualitative Sociology, and "Reporting and the transformations of the journalistic field: US news, media, 1890-2000" in Media, Culture, and Society.

Michael Guggenheim is a Research Fellow in Sociology at Goldsmiths College, London. He works on experts in disasters, architecture and the environment and develops inventive methods together with "shared inc". He has recently published with Jörg Potthast "Symmetrical twins. On the relationship between actor-network theory and the sociology of sociology of critical capacities", in the European Journal of Social Theory and "The laws of foreign buildings: flat roofs and minarets" in Social \& Legal Studies. 